\title{
Of water bags and wind pipes: The travails of securing airway in occipital encephalocoele
}

Despite the advances in the anaesthetic management of neurosurgical patients, difficulty in securing the airway remains a major cause of anesthesia-related morbidity. In this issue of JNRP, Yildırım et al describe their experience in the airway management of 17 neonates with occipital encephalocoele. They describe two simple techniques that they used to overcome the difficulty in securing the airway in their patients. ${ }^{[1]}$

Although encephalocoele surgery has become rare following major improvements in the antenatal care, this problem persists in the rural areas where access to medical care remains far from satisfactory. The two major aims of the anesthesiologists while caring for children with occipital encephalocoele intraoperatively are to avoid premature rupture of the encephalocoele and to manage a possible difficult airway due to restricted neck movement and inability to achieve optimal position for intubation of the trachea.

The largest series of anaesthesia for encephalocoele comprising 118 children with an average age of 1.5 years has been published very recently from the All India Institute of Medical Sciences, New Delhi, India. ${ }^{[2]}$ Occipital encephalocoeles constituted $67 \%$ of the series. Difficult mask ventilation and intubation were encountered in $5.9 \%$ and $19.5 \%$ of children, respectively. Forty-eight percent of children with occipital encephalocoele were intubated by direct laryngoscopy in the lateral position in this series. The majority of the remaining literature is limited to several case reports that have described methods to facilitate intubation in patients with occipital encephalocoele. Quezado et $a l^{[3]}$ and Mowafi et al ${ }^{[4]}$ have used a platform of rolled up blankets with the head hanging from the edge of the table to facilitate intubation in such patients, while Manhas et al used additional manpower to lift the child (one person to support the head and shoulder and a second person to lift the torso

\begin{tabular}{|l|l|}
\hline \multicolumn{2}{|c|}{ Access this article online } \\
\hline Quick Response Code: & Website: \\
\hline & www.ruralneuropractice.com \\
\cline { 2 - 3 } & \\
\hline & \\
\hline
\end{tabular}

and legs) to aid intubation after attempts to intubate in the lateral position failed ${ }^{[5]}$ Dey et al used a third person to extend the neck to successfully intubate a neonate in whom the two earlier described techniques at intubation failed ${ }^{[6]}$ Thus, anesthesiologists have always depended on personal ingenuity and locally available material to tide over the individual crises. No single contraption that assures a high degree of success with certainty has emerged till date.

Several aids, which were not available till a few years ago, are currently in use for securing airway in neonates. ${ }^{[7]}$ Laryngeal mask airway, Truview PCD $^{\mathrm{TM}}$ Infant (Truphatek, Netanya, Israel), AIRTRAQ ${ }^{\circledR}$ Disposable Optical Laryngoscope (Prodol Meditec, Vizcaya, Spain), GlideScope ${ }^{\circledR}$ Video Laryngoscope (Verathon, Bothell, WA, USA), and Storz DCI ${ }^{\circledR}$ Video Laryngoscope (Karl Storz, Tuttlingen, Germany) are being used to facilitate intubation in neonates and smaller children in difficult situations. These devices require familiarity and experience before they can be used successfully. It is important that they be used as first-choice techniques rather than as rescue aids. All the above devices, however, have been used only in non-neurosurgical situations. Experience is lacking with them in a neurosurgical setting and in encephalocoeles, in particular. It remains to be investigated if these devices are helpful in the presence of large encephalocoeles that render supine positioning difficult.

Apart from problems of intubation, there are also other concerns that might need the anesthesiologist's attention in patients with occipital encephalocoele. Jagger et al have reported multiple episodes of raised intracranial pressures and low cerebral perfusion pressures in patients with occipital encephalocoele ${ }^{[8]}$ Creighton et al in a series of 31 patients with occipital encephalocoele have observed disturbances in central autonomic control and defective temperature regulation in these children. ${ }^{[9]}$ In this series, more than $50 \%$ of the patients had non-neurological congenital malformations too, which included extracranial malformations like KlippelFeil deformity (8/31), cleft palate (5/31), hydrocephalus, subglottic stenosis, and micrognathia. All these anomalies could potentially compound the problem of intubation in a patient with large occipital encephalocoele. Other coexisting abnormalities in these patients include 
agenesis of corpus callosum, congenital heart diseases, lumbar meningocoele, and spinal deformities. The physiological immaturity in neonates is another concern as many of these children present for surgery within the first few days after birth.

To summarize, for the time being, airway management in occipital encephalocoele remains a challenge. Anesthesiologists will have to find pragmatic solutions in individual cases, keeping in view the basic tenets of not losing control on the airway and the ability to ventilate until the tracheal tube is safely secured and mechanical ventilation satisfactorily instituted. Problems, outside the airway management, discussed above, also should be given serious consideration. Future studies should evaluate the modern airway gadgets for their suitability in the context of neonatal encephalocoele.

Ganne S Umamaheswara Rao, Sriganesh Kamath

Department of Neuroanaesthesia, National Institute of Mental Health and Neurosciences (NIMHANS), Bangalore, India

Address for correspondence: Dr. G.S Umamaheswara Rao, Department of Neuroanaesthesia, National Institute of Mental Health and Neurosciences (NIMHANS), Bangalore - 560029, India.

\section{References}

1. Yıldırım ZB, Avci E, Torun F, Cengiz M, Karaman H, Çigdem A et al. Airway Management for Occipital Encephalocele in neonatal patients: A review of 17 cases. J Neurosci Rural Pract 2011; 2: 159-61

2. Mahajan C, Rath GP, Dash HH, Bithal PK. Perioperative Management of Children With Encephalocele: An Institutional Experience. J Neurosurg Anesthesiol. 2011 May 31. [In Press]

3. Quezado Z, Finkel JC. Airway Management in Neonates with Occipital Encephalocele: Easy Does It. Anesth Analg 2008;107:1446.

4. Mowafi HA, Sheikh BY, Al-Ghamdi AA. Positioning for anesthetic induction of neonates with encephalocele. Int $J$ Pediatr Neonatol 2001;2:48. Available from: http://www.ispub.com/journal/the_internet_ journal_of_pediatrics_and_neonatology/volume_2_number_2_48/ article/positioning_for_anesthetic_induction_of_neonates_with_ encepalocele_1.html.

5. Manhas Y, Chinnan NK, Singh AK. Neonatal Airway Management in Occipital Encephalocele. Anesth Analg 2006;103:1632.

6. Dey N, Gombar KK, Khanna AK, Khandelwal P. Airway management in neonates with occipital encephalocele: Adjustments and modifications. Paediatr Anaesth 2007;17:1119-20.

7. Holm-Knudsen R. The difficult pediatric airway--a review of new devices for indirect laryngoscopy in children younger than two years of age. Paediatr Anaesth 2011;21:98-103.

8. Jagger KS, Ramkrishna V, Jagtap S, Pantvaidya SH, Modha P. Anaesthesia for excision of occipital encephalocoele. Ind J Anaesth 1986;34:211-5.

9. Creighton RE, Relton JE, Meridy HW. Anaesthesia for occipital encephalocoele. Can Anaesth Soc J 1974;21:403-6.

How to cite this article: Umamaheswara Rao GS, Kamath S. Of water bags and wind pipes: The travails of securing airway in occipital encephalocoele. J Neurosci Rural Pract 2011;2:117-8.

\section{“QUICK RESPONSE CODE” LINK FOR FULL TEXT ARTICLES}

The journal issue has a unique new feature for reaching to the journal's website without typing a single letter. Each article on its first page has a "Quick Response Code". Using any mobile or other hand-held device with camera and GPRS/other internet source, one can reach to the full text of that particular article on the journal's website. Start a QR-code reading software (see list of free applications from http://tinyurl.com/yzlh2tc) and point the camera to the QR-code printed in the journal. It will automatically take you to the HTML full text of that article. One can also use a desktop or laptop with web camera for similar functionality. See http://tinyurl.com/2bw7fn3 or http://tinyurl.com/3ysr3me for the free applications. 